\title{
Feed restriction to induce and meloxicam to mitigate potential systemic inflammation in dairy cows before calving
}

\author{
O. Bogado Pascottini, ${ }^{1 *}$ M. R. Carvalho, ${ }^{2}$ S. J. Van Schyndel, ${ }^{1}$ E. Ticiani, ${ }^{2}$ J. W. Spricigo, ${ }^{2}$ L. K. Mamedova, ${ }^{3}$ \\ E. S. Ribeiro, ${ }^{2}$ and S. J. LeBlanc ${ }^{1}$ \\ ${ }^{1}$ Department of Population Medicine, University of Guelph, Guelph, ON N1G 2W1, Canada \\ ${ }^{2}$ Department of Animal Biosciences, University of Guelph, Guelph, ON N1G 2W1, Canada \\ ${ }^{3}$ Department of Animal Sciences and Industry, Kansas State University, Manhattan 66506
}

\section{ABSTRACT}

Most dairy cows experience a transient decrease in feed intake in the 1 to $2 \mathrm{wk}$ before calving, which has been associated with systemic inflammation (SI), indicated by increased blood haptoglobin (Hp) concentration. We aimed to characterize the association between prepartum decrease in feed intake and the onset of SI and, if present, the ability of meloxicam (MEL), a nonsteroidal anti-inflammatory drug, to mitigate SI. Holstein cows $(\mathrm{n}=45)$ were assigned to control $(\mathrm{n}=13)$, feed restriction (FR) untreated (FR-U; $\mathrm{n}=15)$, and FR treated with MEL (FR-T; n = 17) groups. Daily feed intake was measured from $-22 \mathrm{~d}$ from expected parturition until $35 \mathrm{~d}$ postpartum. Control cows were fed ad libitum, whereas FR-U and FR-T cows were reduced to $60 \%$ of their average intake for 4 consecutive days ( -15 to $-12 \mathrm{~d}$ from expected calving). The FR-T cows received MEL $(0.5 \mathrm{mg} / \mathrm{kg}$ of body weight) once daily for 4 consecutive days $(-13$ to $-10 \mathrm{~d}$ from expected calving). Blood samples were collected $-22,-15,-14$, $-13,-12,-10,-7,-5,-3,0,1,3,5,7,15,22$, and $35 \mathrm{~d}$ relative to calving to measure serum concentrations of total calcium, total protein, albumin, globulin, cholesterol, urea, glucose, gamma-glutamyl transferase, aspartate aminotransferase, glutamate dehydrogenase, $\beta$-hydroxybutyrate, nonesterified fatty acids, Hp, and insulin-like growth factor-1. Serum concentrations of lipopolysaccharide-binding protein were measured -22 , $-15,-14,-13,-12$, and $-10 \mathrm{~d}$ from expected calving. Simplified glucose tolerance tests were performed on $-15,-12,-5,1$, and $5 \mathrm{~d}$ relative to calving. Mixed linear regression models were used to assess the effects of FR and MEL on each metabolite. The interaction between treatment group and blood sampling day was

Received March 1, 2019

Accepted June 12, 2019.

*Corresponding author: obogadop@uoguelph.ca forced into each model. All models accounted for body condition score, parity, and the cow as a random effect. Nonesterified fatty acids concentrations in both the FR-U and FR-T groups significantly increased from the second until the last day of FR. Feed restriction increased urea concentrations compared with the control group on $-14 \mathrm{~d}$ but decreased urea concentrations on $-10 \mathrm{~d}$ from expected calving. Control cows had greater $\beta$-hydroxybutyrate concentrations compared with FR cows on 15, 21, and $35 \mathrm{~d}$ postpartum. For all other metabolites, no differences were found. This model of FR produced substantial fat mobilization but based on serum $\mathrm{Hp}$ and lipopolysaccharide-binding protein concentrations did not generate measurable SI; therefore, we were unable to evaluate the ability of MEL to mitigate SI.

Key words: transition period, nonsteroidal antiinflammatory, metabolic inflammation

\section{INTRODUCTION}

The transition period is critical for dairy cows due to the disproportionately high incidence of health problems in a short time (Drackley, 1999). Between 30 and 50\% of dairy cows experience metabolic or infectious disease during the transition from late gestation to early lactation (LeBlanc, 2010). Briefly, the homeostatic balance in postpartum cows is disrupted by the homeorhetic redirection of nutrients toward the mammary gland in support of milk production. This phenomenon is often concurrent with a reduction in feed intake (Grummer, 1995), resulting in a negative energy balance of varying duration and intensity. Concomitantly, dysregulation of inflammation, impaired neutrophil function, and environmental stressors (e.g., social group changes) make dairy cows more prone to developing metabolic or infectious diseases (Mulligan and Doherty, 2008; Ingvartsen and Moyes, 2015).

There is a physiologically normal level of inflammation associated with parturition, placental expulsion, 
and uterine involution, but dysregulation of inflammation can have deleterious effects. There is growing recognition that inflammation is not only a reaction to injury or disease but also a precursor and contributor to metabolic disease (Medzhitov, 2008). Most postpartum dairy cows develop a type of aseptic inflammation, referred to as systemic inflammation (SI). This SI originates from the production of proinflammatory cytokines, such as IL-1 $\beta$, IL-6, and tumor necrosis factor (TNF)- $\alpha$ (Gabay and Kushner, 1999; Bertoni et al., 2015; Bradford et al., 2015). One source of these proinflammatory mediators is the inherent inflammatory process in the postpartum uterus, and potentially another is the mobilization of fat triggered by the negative energy balance status (LeBlanc, 2012; Bertoni et al., 2015). In the liver, these cytokines stimulate the production of positive acute phase proteins (APP) and reduce the synthesis of negative APP (Gabay and Kushner, 1999; Kindt et al., 2007; Bertoni et al., 2008). High concentrations of haptoglobin $(\mathbf{H p})$ in the postpartum period are associated with impaired neutrophil function (Wittrock, 2012) and are risk factors for postpartum uterine disease (Dubuc et al., 2010). Lower concentrations of negative APP (e.g., albumin) are associated with decreased liver function, fertility, and milk yield (Bionaz et al., 2007; Bertoni et al., 2008).

Mobilization of adipose, especially visceral fat, leads to the production of TNF- $\alpha$ and IL-6 (Tilg and Moschen, 2008; Trevisi et al., 2012), which block the intracellular signaling of insulin. The early-lactation period causes a loss of adipocyte sensitivity to insulin, which supports a state of insulin resistance in adipose tissue of postpartum cows and thus exacerbates the release of nonesterified fatty acids (NEFA) from adipose (De Koster et al., 2018). The liver of a postpartum dairy cow uses NEFA from the blood and either stores them as triglycerides or oxidizes them to acetyl coenzyme A. The excessive storage of NEFA as triglycerides and the oxidation of NEFA compromises liver function, and oxidation suppresses feed intake (Allen and Piantoni, 2013). Fluctuations in the feed intake pattern, including temporarily reduced feed intake throughout the periparturient period and increased or fluctuating intake postpartum, may provoke SARA (SchwartzkopfGenswein et al., 2003; Marques et al., 2012). Subacute ruminal acidosis disrupts the integrity of the ruminal epithelium, allowing the absorption of bacterial LPS (Bradford et al., 2015). Circulating LPS binds to LPSbinding protein (LBP; Sweet and Hume, 1996), a positive APP that plays a role in the neutralization of the effect of LPS to induce inflammatory responses (Gallay et al., 1994).
Studies involving transition cows are most commonly focused on the postpartum period. However, lipolysis may begin several weeks prepartum, with decreases in plasma insulin concentration and liver and fat tissue insulin sensitivity (Morino et al., 2006; Zachut et al., 2013). Trevisi et al. (2012) proposed that greater inflammatory status starting before calving is reflected in a lower liver functionality index based on changes in concentrations of albumin, cholesterol, and bilirubin in early lactation. Bertoni et al. (2009) demonstrated that cows with a substantial spontaneous decrease in DMI starting 2 wk before calving had a concurrent marked increased in circulating Hp concentration. Trevisi et al. (2012) hypothesized that dysregulated inflammatory response before calving is likely to trigger subsequent reduced immune function that may be associated with the onset of transition disease. However, the reasons for reduced feed intake in the prepartum period are poorly understood. The experimental use of nonsteroidal antiinflammatory drugs (NSAID) may help explain the physiology behind reduced feed intake and SI in the prepartum period. Previous experiments with oral antiinflammatory medication in the first week postpartum resulted in unfavorable responses of lower glucose and higher NEFA. However, treated cows had greater liver insulin sensitivity in the short term and produced more milk in the whole lactation (Farney et al., 2013a,b; Montgomery et al., 2019). The increased milk production effect of early postpartum treatment with NSAID has been replicated, but the metabolic effects are not consistent (Carpenter et al., 2016). For an NSAID to be considered advantageous in a commercial setting, it should have an anti-inflammatory effect for a useful duration. Meloxicam (MEL) reaches a peak drug concentration $4 \mathrm{~h}$ after subcutaneous injection and has a half-life of $26 \mathrm{~h}$ in adult cattle (EMEA, 2007). It functions by selectively inhibiting COX-2, and its use in other species of mammals results in lower incidence of adverse effects compared with other NSAID (Brideau et al., 2001). Due to its relatively long half-life in cattle and because it is approved for use in cows in Canada for other indications, MEL is ideal for experimental settings in Canada.

We hypothesized that feed restriction (FR) in the prepartum period would trigger fat mobilization and subsequent release of proinflammatory cytokines and SI and that MEL treatment of FR cows would attenuate SI. This model would test the hypothesis that decreased feed intake contributes to the development of SI. Thus, the objective of this proof-of-concept study was to assess the association between prepartum FR and the onset of SI and, if present, the ability of MEL 
treatment to mitigate SI and reduce the incidence of resultant metabolic disturbances in postpartum dairy cows.

\section{MATERIALS AND METHODS}

\section{Animals, Housing, and Management}

This study was conducted from September 2017 to January 2018 at the University of Guelph Livestock Research and Innovation Centre Dairy Facility (Elora, ON, Canada). Cows were managed according to the guidelines set by the Dairy Farmers of Canada and the National Farm Animal Care Council (DFC-NFACC, 2009), and the animal utilization protocol was approved by the University of Guelph Animal Care Committee. Fifty-five pregnant nonlactating Holstein cows [17 nulliparous and 38 parous; parity $=1.1 \pm 0.96$ (mean \pm SD)] were initially included. Cows were enrolled $25 \mathrm{~d}$ before their expected calving date with an average BCS of $3.7 \pm 0.2$ (1- to 5-point scale, measured in 0.25-point increments; Ferguson et al., 1994). Expected calving was calculated as $280 \mathrm{~d}$ after the last insemination date. Cows were housed 12 animals at a time in a close-up pen with 12 automated feed bins, 24 freestalls, and ad libitum access to water. Each cow was trained to eat from individually assigned automated feed bins (Insentec B.V., Marknesse, the Netherlands) that measured daily feed intake. Cows with external signs of preparation for calving (e.g., swelling of the vulva and relaxation of the pelvic ligaments) were moved to individual calving pens with access to feed and water as in the freestall pen. After calving, cows were milked twice daily. At 3 to $5 \mathrm{~d}$ postpartum, cows determined to be clinically healthy by farm personnel were relocated to a lactating pen. Each lactating pen housed 15 cows at a time with 15 automated feed bins, 30 freestalls, and ad libitum access to water. Cows were milked twice daily (0500 and $1700 \mathrm{~h})$ in a rotary parlor. Daily feed intake was recorded from $25 \mathrm{~d}$ before expected parturition until $35 \mathrm{~d}$ postpartum. Cows were fed once daily in the morning (1100 h for dry cows and $1300 \mathrm{~h}$ for lactating cows) after cleaning out of each feed bin. Maternity pens were not equipped with automated feed bins; therefore, the amount of offered and refused feed was manually weighed daily by farm personnel.

\section{Study Design}

The sample size calculation of this nonrandomized controlled trial was based on the effect of antiinflammatory treatment using $80 \%$ power and a $95 \%$ confidence level. For the main effect of FR, the primary marker of inflammatory response required at least 10 cows per treatment, which allows for detection of a difference of $0.5 \mathrm{~g} / \mathrm{L}(\mathrm{SD}=0.4)$ in serum Hp. At enrollment, cows were deliberately and nonrandomly assigned to experimental treatment groups to balance for BCS and parity. To manage feed deliveries according to the study protocol, the investigators were not blinded to treatment assignments. Experimental groups consisted of control $(\mathrm{n}=16), \mathrm{FR}$ untreated $(\mathbf{F R}-\mathbf{U} ; \mathrm{n}=19)$, and FR treated with an anti-inflammatory $(\mathbf{F R}-\mathbf{T} ; \mathrm{n}=20)$. The slightly greater number of cows in the FR groups was deliberate to account for expected greater variance in Hp among cows on FR. The first 3 consecutive days after enrollment ( -25 to $-22 \mathrm{~d}$ from expected calving) were considered the training period for cows learning to eat from individually assigned feed bins. Control cows were fed ad libitum, whereas FR-U and FR-T cows were reduced to $60 \%$ of their average intake for 4 consecutive days ( -15 to $-12 \mathrm{~d}$ from expected calving). The $40 \%$ daily FR was based on the average feed intake from -22 to $-16 \mathrm{~d}$ from expected calving (measured daily by the individual bins) and was intended to result in cows consuming less than their maintenance energy requirement. The FR- $\mathrm{T}$ cows received a subcutaneous injection of MEL $(0.5 \mathrm{mg} / \mathrm{kg}$ of BW; Boehringer Ingelheim Ltd., Burlington, ON, Canada) once daily for 4 consecutive days ( -13 to $-10 \mathrm{~d}$ from expected calving). We hypothesized that FR would not immediately trigger SI; therefore, MEL treatment started only on the second day after FR was initiated. Control cows and FR-T cows did not receive any injections. When not FR, the total amount of feed offered was adjusted daily to target approximately $10 \%$ refusals per bin in each of the groups. All groups received a common TMR during the dry and fresh periods. Throughout the study, pre- and postpartum TMR feed samples were collected weekly and immediately frozen at $-20^{\circ} \mathrm{C}$ until further analysis. The diets and chemical composition of TMR samples are shown in Table 1.

\section{Blood Sampling}

Whole-blood samples were collected from coccygeal vessels using 20-gauge, 2.54 -cm hypodermic needles into sterile glass Vacutainer tubes without anticoagulant (BD Vacutainer Precision Glide, Becton Dickinson, Franklin Lakes, NJ). Samples were obtained $-22,-15$, $-14,-13,-12,-10,-7,-5,-3,0,1,3,5,7,15,22$, and $35 \mathrm{~d}$ relative to calving. All samples were collected between 0800 and $0900 \mathrm{~h}$, placed in a refrigerated container, and centrifuged at $1,500 \times g$ for $15 \mathrm{~min}$ at $18^{\circ} \mathrm{C}$ within $2 \mathrm{~h}$ of collection. Serum was separated into 4 aliquots and stored at $-20^{\circ} \mathrm{C}$ until further analysis. At the conclusion of the experiment, serum samples were used to measure the concentrations of total calcium, 
Table 1. Descriptive summary of feed and nutrient analysis for TMR for dry cows $(-22$ to $0 \mathrm{~d}$ from expected calving) and for lactating cows ( 1 to $35 \mathrm{~d}$ from calving) for 45 Holstein cows ${ }^{1}$

\begin{tabular}{|c|c|c|}
\hline \multirow[b]{2}{*}{ Item } & \multicolumn{2}{|c|}{ TMR } \\
\hline & Dry cow & Lactating cow \\
\hline \multicolumn{3}{|l|}{ Ingredient $(\%$ of $\mathrm{DM})$} \\
\hline Straw & 27.4 & 1.7 \\
\hline Haylage & 11.8 & 32.8 \\
\hline Corn silage & 33.3 & 33.8 \\
\hline High-moisture corn & - & 19.5 \\
\hline Concentrate mix & 27.5 & 12.2 \\
\hline \multicolumn{3}{|c|}{ Concentrate composition $(\mathrm{mg} / 1,000 \mathrm{~kg}$ of mix $)$} \\
\hline Soy Plus ${ }^{2}$ & 250 & 380 \\
\hline Animate $^{3}$ & 125.6 & - \\
\hline Beet pulp & 110 & - \\
\hline Oat hulls & 109 & - \\
\hline Soybean meal $47 \%$ & 100 & 260.9 \\
\hline Canola & 70 & 100 \\
\hline Wheat shorts & - & 100 \\
\hline Sodium sesquicarbonate & - & 37 \\
\hline Limestone calcium carbonate & 65 & 33 \\
\hline Bran & 55 & - \\
\hline Soy hulls (ground) & 53 & - \\
\hline Molasses (mixer) & 24 & - \\
\hline Yeast & 11.2 & 16.5 \\
\hline Calcium sulfate & 8 & - \\
\hline Monocalcium phosphate & - & 7.50 \\
\hline Fine salt & 6 & 34 \\
\hline Vitamin E $(50$ kIU/kg) & 5.7 & - \\
\hline Selenium & 3 & 2.86 \\
\hline FFM Org Ruminant Micro ${ }^{4}$ & 2.1 & 5.39 \\
\hline Sulfur $99.5 \%$ & & 3 \\
\hline Magnesium oxide & 2 & 0.36 \\
\hline Rumensin $/ \operatorname{coban}^{5}$ & 0.3 & 0.44 \\
\hline Rovimix Biotin 20,000 & 0.1 & - \\
\hline MetaSmart $^{7}$ & - & 6.72 \\
\hline Micro-Aid feed-grade concentrate ${ }^{8}$ & - & 0.33 \\
\hline \multicolumn{3}{|c|}{ Item $^{9}$ ( $\%$ of DM, unless otherwise indicated) } \\
\hline $\mathrm{DM}(\%)$ & $54.8 \pm 2.1$ & $44.1 \pm 0.7$ \\
\hline $\mathrm{CP}$ & $13.1 \pm 0.4$ & $15.6 \pm 0.3$ \\
\hline Soluble protein & $4.0 \pm 0.2$ & $5.4 \pm 0.5$ \\
\hline $\mathrm{ADF}$ & $28.4 \pm 1.7$ & $20.2 \pm 1.7$ \\
\hline NDF & $42.7 \pm 2.0$ & $33.3 \pm 1.0$ \\
\hline Lignin & $4.3 \pm 0.1$ & $3.5 \pm 0.5$ \\
\hline Fat & $2.7 \pm 4.6$ & $3.3 \pm 0.2$ \\
\hline Starch & $14.8 \pm 1.6$ & $23.3 \pm 1.0$ \\
\hline NFC & $38.8 \pm 2.3$ & $44.2 \pm 1.0$ \\
\hline Ash & $6.8 \pm 0.2$ & $7.0 \pm 0.1$ \\
\hline $\mathrm{Ca}$ & $1.0 \pm 0.1$ & $0.8 \pm 0.1$ \\
\hline $\mathrm{P}$ & $0.2 \pm 0.1$ & $0.3 \pm 0.1$ \\
\hline $\mathrm{K}$ & $1.1 \pm 0.1$ & $1.3 \pm 0.1$ \\
\hline $\mathrm{Mg}$ & $0.4 \pm 0.1$ & $0.3 \pm 0.1$ \\
\hline $\mathrm{Na}$ & $0.1 \pm 0.1$ & $0.3 \pm 0.1$ \\
\hline $\mathrm{NE}_{\mathrm{t}}(\mathrm{Mcal} / \mathrm{kg}$ of $\mathrm{DM})$ & $1.4 \pm 0.1$ & $1.5 \pm 0.1$ \\
\hline DCAD $(\mathrm{mEq} / 100 \mathrm{~g})$ & $11.9 \pm 2.6$ & \\
\hline
\end{tabular}

${ }^{1}$ Based on the analysis of $n=12$ feed samples per group. Treatment groups consisted of control $(n=13)$, feed restriction $(\mathrm{FR})$ untreated $(\mathrm{FR}-\mathrm{U} ; \mathrm{n}=15)$, and $\mathrm{FR}$ treated with meloxicam $(\mathrm{FR}-\mathrm{T} ; \mathrm{n}=17)$. All groups received common TMR during the dry and fresh periods. Control cows were fed ad libitum, whereas FR-U and FR-T cows were reduced to $60 \%$ of their average intake for $4 \mathrm{~d}$ ( -15 to $-12 \mathrm{~d}$ from expected calving). The FR-T cows received meloxicam $(0.5 \mathrm{mg} / \mathrm{kg}$ of BW) once daily for $4 \mathrm{~d}$ ( -13 to $-10 \mathrm{~d}$ from expected calving).

${ }^{2}$ Bypass soybean meal (Landus Cooperative, Ames, IA).

${ }^{3}$ Anionic mineral supplement (Phibro Animal Health Corp., Teaneck, NJ).

${ }^{4}$ Trace mineral and vitamin premix containing 5 organic microminerals (zinc, manganese, copper, cobalt, and selenium; Floradale Feed Mill, Floradale, ON, Canada).

${ }^{5}$ Rumensin 200 (Elanco, Guelph, ON, Canada).

${ }^{6}$ Water-soluble B vitamin $(20,000 \mu \mathrm{g} / \mathrm{kg}$; DSM, Heerlen, the Netherlands).

${ }^{7}$ Rumen-protected methionine (Adisseo, Alpharetta, GA).

${ }^{8}$ Environmentally safe odor-eliminating product (DPI Global, Porterville, CA).

${ }^{9}$ Values are mean $\pm \mathrm{SD}$. 
total protein, albumin, globulin, cholesterol, urea, glucose, gamma-glutamyl transferase (GGT), aspartate aminotransferase (AST), glutamate dehydrogenase (GLDH), BHB, NEFA, and Hp (collectively, a metabolic profile) as well as IGF-1, IL-1 $\beta$, IL-6, and TNF- $\alpha$ at each of the time points. The concentration of LBP was measured at $-22,-15,-14,-13,-12$, and -10 $\mathrm{d}$ from expected calving (around the FR period). The time of blood sampling prepartum was based on the expected calving date from -22 to $-10 \mathrm{~d}$. From $-7 \mathrm{~d}$ until calving, the time of sampling is reported based on the actual calving date.

Serum samples for the metabolic profile were processed by the University of Guelph Animal Health Laboratory (Guelph, ON, Canada). Total calcium, total protein, albumin, globulin, cholesterol, urea, glucose, GGT, AST, and GLDH serum concentrations were measured using an autochemistry analyzer (Cobas 6000 c 501, Roche Diagnostics, Indianapolis, IN). Nonesterified fatty acids and BHB serum concentrations were measured using Randox NEFA and BHB kits (Randox Laboratories Canada Ltd., Mississauga, ON, Canada). Serum Hp concentration was measured by the hemoglobin binding capacity method (Makimura and Suzuki, 1982; Skinner et al., 1991). A summary of the analytical sensitivities and intra-assay coefficients of variation for each of the serologic variables analyzed in the metabolic profile is presented in Supplemental Table S1 (https://doi.org/ 10.3168/jds.2019-16558).

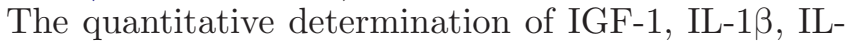
6, LBP, and insulin was performed in our laboratory. For IGF-1, a human immunoassay (Quantikine ELISA, R\&D Systems, Minneapolis, MN) was used. The sequence of human IGF-1 is identical to that of bovines (Tavakkol et al., 1988). The detection limit of the assay is $0.026 \mu \mathrm{g} / \mathrm{L}$, and the intra- and interassay coefficients of variation were 5.6 and $7.1 \%$, respectively. The concentrations of IL- $1 \beta$ and IL- 6 were analyzed using commercially available ELISA kits specific to the bovine species (Pierce, Thermo Scientific, Rockford, IL). The analytical sensitivity of IL- $1 \beta$ and IL- 6 are 31.3 and $78.1 \mathrm{pg} / \mathrm{mL}$, respectively. Lipopolysaccharide-binding protein concentration was determined using a commercially available LBP ELISA kit cross-reacting with bovine LBP (LBP ELISA for various species, Hycult Biotechnology, Uden, the Netherlands). The analytical sensitivity of LBP is $1.6 \mathrm{ng} / \mathrm{mL}$. Serum samples were diluted 1:1,000 (Suojala et al., 2008), and the intra- and interassay coefficients of variation were 7.2 and $9.9 \%$, respectively. The quantitative determination of insulin was performed using a bovine-specific insulin ELISA (Mercodia AB, Uppsala, Sweden). The detection limit of the assay is $0.025 \mu \mathrm{g} / \mathrm{L}$. Samples from the 10-min point of the glucose tolerance test (GTT) were diluted
$1: 10$, and the intra- and interassay coefficients of variation were 6.5 and $9.3 \%$, respectively. The IGF-1, IL-1 $\beta$, IL-6, LBP, and insulin ELISA microplates were read with a spectrophotometer (EON, Biotek, Winooski, $\mathrm{VT}$ ). The concentration of TNF- $\alpha$ was determined using the methods described by Farney et al. (2011) at the Kansas State University Department of Animal Sciences and Industry with an analytical sensitivity of $2 \mathrm{pg} / \mathrm{mL}$. Induction of SI was defined by differences in circulating biomarkers of inflammation between treatment groups - specifically, increased IL-1 $\beta$, IL-6, TNF- $\alpha, H p$, and LBP concentrations and decreased albumin concentrations.

\section{GTT}

Simplified GTT (Matteo et al., 2009; Miltenburg et al., 2018) were performed $-15,-12,-5,1$, and $5 \mathrm{~d}$ relative to calving to examine the hypothesis that SI would alter insulin responses. All GTT were initiated between 0900 and $1000 \mathrm{~h}$, with feed but not water withheld $3 \mathrm{~h}$ before and during the GTT. The GTT consisted of jugular intravenous administration of $0.25 \mathrm{~g}$ of dextrose/kg of BW (dextrose 50\%; Vétoquinol Canada Inc., Lavaltrie, QC, Canada) over 2 min. A baseline blood sample (0 min) was collected immediately before, followed by samples from coccygeal vessels 10,60 , and 80 min after the dextrose infusion from coccygeal vessels. All blood samples were collected in tubes without anticoagulant (BD Vacutainer Precision Glide, Becton Dickinson), placed on ice, and centrifuged at 1,500 $\times$ $g$ for $15 \mathrm{~min}$ at $18^{\circ} \mathrm{C}$ within $2 \mathrm{~h}$ of sampling. Serum samples were separated into 3 aliquots per time point and stored at $-20^{\circ} \mathrm{C}$. At the end of the experiment, GTT serum samples were used to evaluate glucose and insulin concentrations at each time point.

\section{Statistical Analysis}

All data were exported to Microsoft Excel (Microsoft Corp., Redmond, WA), where data exploration and organization were done using the PivotTables function. All statistical analyses were done using R-core version 3.3.0 (R Core Team, Vienna, Austria). The function summary of the R code system (package Base) was used for the descriptive statistical analyses. Continuous outcomes were $\log _{10}$ transformed when the Shapiro-Wilk test determined that they were not normally distributed. For all statistical analyses, the cow was included as a random effect. Significance and tendency levels were declared at $P<0.05$ and $P<0.1$, respectively.

The function lmer of the package lme4 (Bates et al., 2015) was used to fit mixed linear regression models. The effects of BCS at enrollment, parity, blood sam- 
pling day relative to calving (time of sampling), and treatment were tested for each blood metabolite (total calcium, total protein, albumin, globulin, cholesterol, urea, glucose, GGT, AST, GLDH, BHB, NEFA, Hp, IGF-1, and LBP). Time of sampling was included as a repeated measure. Because the main effects of treatment (control, FR-U, and FR-T) and time of sampling were important variables of interest for this study, these main effects and their interactions were forced into each model. A $\log _{10}$ transformation of raw value +1 was used to normalize AST, GLDH, BHB, and Hp distributions. Parity was classified as nulliparous and parous cows, and BCS at enrollment was classified as $\leq 3.5$ and $\geq 3.75$. Feed intake and daily milk production were also modeled with the lmer function to test the treatment effect using the repeated measurement statement, with BCS and parity as covariates. The GTT data $(-15,-12,-5,1$, and $5 \mathrm{~d}$ from calving) were also fitted with mixed linear regression models. The area between the insulin and glucose curves was calculated by the total area method using the trapezoidal rule (Cardoso et al., 2011) to explore the effect of treatment on glucose tolerance, including BCS and parity as covariates. For the GTT data, serum glucose and insulin concentrations before the dextrose infusion were used to calculate a baseline for each animal. For all models, first-order interactions between the treatment group (control vs. FR-U vs. FR-T and control vs. FR) and each covariate were tested and retained when significant. For all outcomes, the baseline measurement was included as covariate to account for pretreatment values. The Tukey multiple differences test (glht function, multcomp package; Hothorn et al., 2013) was used to compare experimental groups, by day where appropriate. All results are expressed as least squares means with their respective standard errors.

\section{RESULTS}

From the 55 dry Holstein cows initially included at $-25 \mathrm{~d}$ from expected calving, a total of 10 cows were excluded before $35 \mathrm{~d}$ postpartum. The reasons for exclusion were early calving $(\mathrm{n}=2)$, prepartum injury ( $\mathrm{n}$ $=1$ ), caesarean section $(\mathrm{n}=2)$, and transition diseases (milk fever, $\mathrm{n}=3$; displaced abomasum, $\mathrm{n}=2$ ). The final data set comprised 45 Holstein cows (14 nulliparous and 31 parous) that completed the transition period (from -25 until $35 \mathrm{~d}$ postpartum) without clinical disease. Only cows that calved at least $5 \mathrm{~d}$ after the end of the FR were included in the final analyses. The composition of the experimental groups was as follows: control, $\mathrm{n}=13$, BCS at enrollment $=3.8 \pm 0.2$, parity $=1.2 \pm 1.0 ;$ FR-U, $\mathrm{n}=15, \mathrm{BCS}$ at enrollment $=3.7$ \pm 0.2 , parity $=1.1 \pm 1.0$; and FR-T, $\mathrm{n}=17$, BCS at enrollment $=3.7 \pm 0.2$, parity $=1.1 \pm 0.9$. Based on the actual calving date, FR started $12.6 \pm 3.6 \mathrm{~d}$ (FR$\mathrm{U}$ at $13.1 \pm 3.6 \mathrm{~d}$ and FR-T at $12.2 \pm 3.5 \mathrm{~d}$ ) before parturition. None of the measurements of interest were different among groups at the baseline sample $(P>$ $0.4)$.

\section{Effect of Treatment on DMI and Milk Production}

The daily DMI of each of the experimental groups is depicted in Figure 1. The mean DMI during the FR period ( -15 until $-12 \mathrm{~d}$ from expected calving) was $10.1 \pm 2.6 \mathrm{~kg}$ for FR-U and $9.2 \pm 2.4 \mathrm{~kg}$ for FR-T. This FR correspond to a DMI reduction of $38.1 \%$ for FR-U and $39.5 \%$ for FR-T from their DMI from -22 until $-16 \mathrm{~d}$ from expected calving $(16.3 \pm 2.6 \mathrm{~kg}$ for FR-U and $15.2 \pm 2.4 \mathrm{~kg}$ for FR-T). The DMI of control cows was similar from -22 until $16 \mathrm{~d}(16.1 \pm 3.9$ $\mathrm{kg})$ and from -15 until $-12 \mathrm{~d}(15.7 \pm 3.8 \mathrm{~kg})$ from expected calving. The DMI from -15 until $-12 \mathrm{~d}$ from expected calving was $37 \%$ greater for the control group compared with the FR groups. The day after the end of the FR ( $-11 \mathrm{~d}$ from expected calving), FR cows ate $20 \%(16.7 \pm 3.4 \mathrm{~kg})$ more than the control cows $(13.4 \pm 3.4 \mathrm{~kg})$. No differences were found between FR groups (FR-U vs. FR-T) in DMI at any time point $(P$ $=0.8$ ). Mean daily milk production to 35 DIM was $36 \pm 11.2 \mathrm{~kg}(26.2 \pm 7.2 \mathrm{~kg}$ for primiparous cows and $40.9 \pm 9.5 \mathrm{~kg}$ for parous cows), which was not different among experimental groups $(P=0.82 ; 36.8 \pm 10.5 \mathrm{~kg}$ for control, $35.1 \pm 11.7 \mathrm{~kg}$ for FR-U, and $36.8 \pm 11.1$ kg for FR-T; Supplemental Figure S1, https://doi.org/ 10.3168/jds.2019-16558).

\section{Effect of Treatment on Blood Metabolites}

All blood metabolites changed $(P<0.05)$ over time independent of treatment. Serum Hp concentrations did not differ among treatments $(P=0.9$; Figure 2$)$. Total calcium, total protein, albumin, globulin, cholesterol, glucose, GGT, AST, GLDH, IGF-1, and LBP concentrations were not different among experimental groups $(P>0.7$; Supplemental Figures S2 to S12, https: //doi.org/10.3168/jds.2019-16558). Compared with the control group, NEFA concentrations in both FR groups increased and were greater than those in the control group from the second until the last day of FR (Figure 3 ). However, serum NEFA concentrations was similar between the FR-U and FR-T groups $(P=0.9$; Figure $3)$. The FR cows had greater serum urea concentrations compared with the control group on $-14 \mathrm{~d}$ (FR-U, $P$ $=0.01 ; \mathrm{FR}-\mathrm{T}, P=0.04)$ but lesser concentrations of serum urea compared with the control group on -10 $\mathrm{d}$ from expected calving (FR-U, $P=0.001$; FR-T, $P$ 
$=0.01 ;$ Figure 4). No differences were found between FR groups (FR-U and FR-T) in urea concentrations at any time point $(P=0.8$; Figure 4$)$. Control cows had greater BHB concentrations than FR cows on 15, 21, and 35 d postpartum (Figure 5). No differences in serum BHB concentrations were found between FR groups $(P=0.8$; Figure 5$)$.

For IL-1 $\beta$, a total of 360 serum samples from 17 (control $=5$, FR-U $=7$, FR-T $=5$ ) cows were analyzed. However, none of the samples were above the limit of detection. For IL-6, a total of 351 serum samples from 16 cows (control $=4, \mathrm{FR}-\mathrm{U}=7$, and FR-T $=5$ ) were analyzed and only $24 \%$ of samples $(\mathrm{n}=83)$ from 6 cows provided results above the limit of detection, with a mean serum concentration of $487 \pm 268 \mathrm{pg} / \mathrm{mL}$. Sixty-one percent of samples $(\mathrm{n}=51)$ above the limit of detection for IL- 6 were collected in the postpartum period. For TNF- $\alpha$, a total of 300 samples from 18 cows (control $=6, \mathrm{FR}-\mathrm{U}=6$, and FR-T $=6$ ) were analyzed and only $37 \%$ of samples $(n=112)$ from 7 cows provided results above the limit of detection, with a mean serum concentration of $10 \pm 8 \mathrm{pg} / \mathrm{mL}$. Sixty-five percent of samples $(n=73)$ above the limit of detection for TNF- $\alpha$ were collected in the postpartum period. Most of the serum samples that provided values above the detection limit for IL-6 and TNF- $\alpha$ were from multiple samples of the same cow. For all analyzed cytokines, the standards for the ELISA assays were always detected in their respective range. Because the serum concentrations of most of the analyzed cytokines (IL-1 $\beta$, IL-6, and TNF- $\alpha$ ) were below the detection limits for most or all samples, no statistical analyses were undertaken.

\section{Effect of Treatment on GTT}

The concentrations of insulin and glucose at each time point of the GTT performed $-15,-12,-5,1$, and $5 \mathrm{~d}$ relative to calving are illustrated in Supplemental

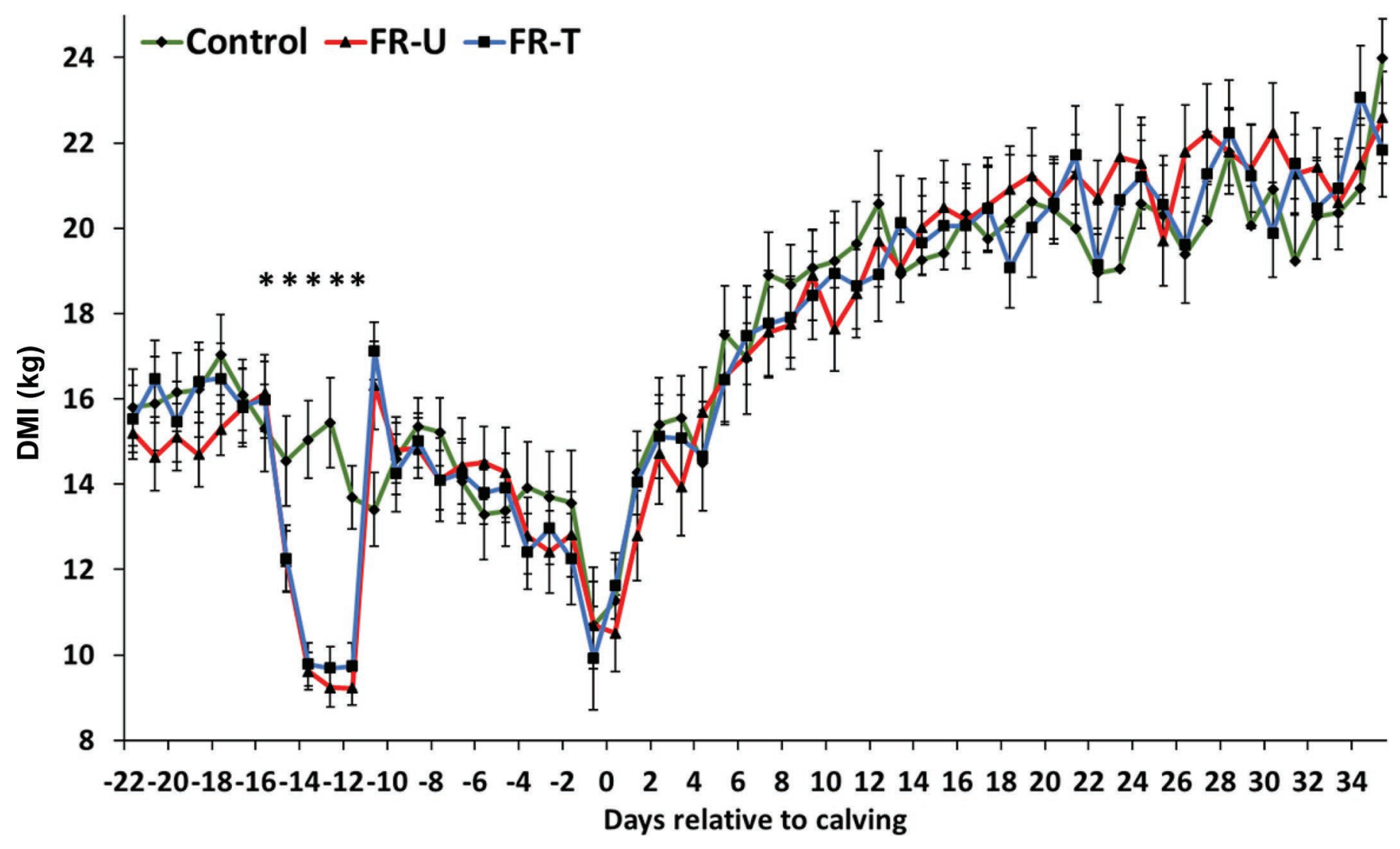

Figure 1. Least squares means (accounting for parity and BCS) \pm SE of DMI of Holstein cows $(\mathrm{n}=45)$ from -22 until $35 \mathrm{~d}$ from calving. Treatment groups were control $(\mathrm{n}=13)$, feed restriction $(\mathrm{FR})$ untreated $(\mathrm{FR}-\mathrm{U} ; \mathrm{n}=15)$, and FR treated with meloxicam $(\mathrm{FR}-\mathrm{T} ; \mathrm{n}=$ 17). Control cows were fed ad libitum, whereas FR-U and FR-T cows were reduced to $60 \%$ of their average intake for $4 \mathrm{~d}(-15$ to $-12 \mathrm{~d}$ from expected calving). The FR-T cows received meloxicam $(0.5 \mathrm{mg} / \mathrm{kg}$ of BW) once daily for $4 \mathrm{~d}$ ( -13 to $-10 \mathrm{~d}$ from expected calving). From -15 until $-12 \mathrm{~d}$ from expected calving, DMI was lower in the FR cows compared with the control cows (FR-U: $P=0.03,0.001,0.002$, and 0.01 on $-15,-14,-13$, and $-12 \mathrm{~d}$, respectively; FR-T: $P=0.04,0.0009,0.0002$, and 0.01 on $-15,-14,-13$, and $-12 \mathrm{~d}$, respectively). The day after the end of the FR ( $-11 \mathrm{~d}$ from expected calving), FR-U and FR-T cows ate more than control cows $(P=0.03$ and 0.007 , respectively). Asterisks indicate significant differences $(P<0.05)$ between the control and the FR groups at $\mathrm{d}-15,-14,-13,-12$, and -11 . No differences were found between FR groups (FR-U vs. FR-T) at any time point $(P=0.8)$. 
Figure S13 (https://doi.org/10.3168/jds.2019-16558). There were no differences among treatments in the area between the glucose and insulin curves. Based on the actual calving date, $-15,-12$, and $-5 \mathrm{~d}$ GTT were performed $-13.1 \pm 3.6,-10.1 \pm 3.6$, and $-2.8 \pm 2.4 \mathrm{~d}$ relative to calving, respectively. Glucose tolerance tests on $-5 \mathrm{~d}$ relative to calving were performed in 36 cows ( control $=12, \mathrm{FR}-\mathrm{U}=12$, and FR-T $=12$ ) due to early calving in 9 cows.

\section{DISCUSSION}

In dairy cattle, there are competing hypotheses about whether SI is a consequence of, or contributor to, the reduction in feed intake before calving. This study prospectively explored whether SI developed as a result of reduction in feed intake before calving and aimed to assess whether anti-inflammatory intervention could mitigate peripartum SI. We used a model of FR to mimic that seen in the week before calving, expected fat mobilization, and consequent release of proinflammatory cytokines (TNF- $\alpha$ in particular) to trigger SI. This FR model produced substantial fat mobilization based on the high concentrations of NEFA. However, this fat mobilization did not generate SI (based on Hp, LBP, and albumin concentrations); therefore, the ability of MEL to mitigate SI could not be properly assessed.

The capabilities of our research farm allowed us to monitor and manipulate the individual feed intake in freestall-housed cows. Each of the experimental groups were deliberately balanced by BCS and parity. We started the FR at $14 \mathrm{~d}$ before expected calving based on the observations described by Bertoni et al. (2009), where in some cows a substantial decrease in DMI was observed 1 to 2 wk before calving, concurrent with an increase in plasma Hp concentration. The DMI was similar among experimental groups in the week previous to the FR. The prepartum $40 \%$ FR model produced significant fat mobilization as indicated by $>2$-fold greater NEFA concentration from the second until the last day of restriction ( -14 to $-12 \mathrm{~d}$ from expected calving) in the FR cows. Prepartum NEFA during FR were $\geq 0.3$ $\mathrm{mmol} / \mathrm{L}$, a threshold associated with increased risk of disease (McArt et al., 2013). However, this increase in serum NEFA represented approximately $50 \%$ of the

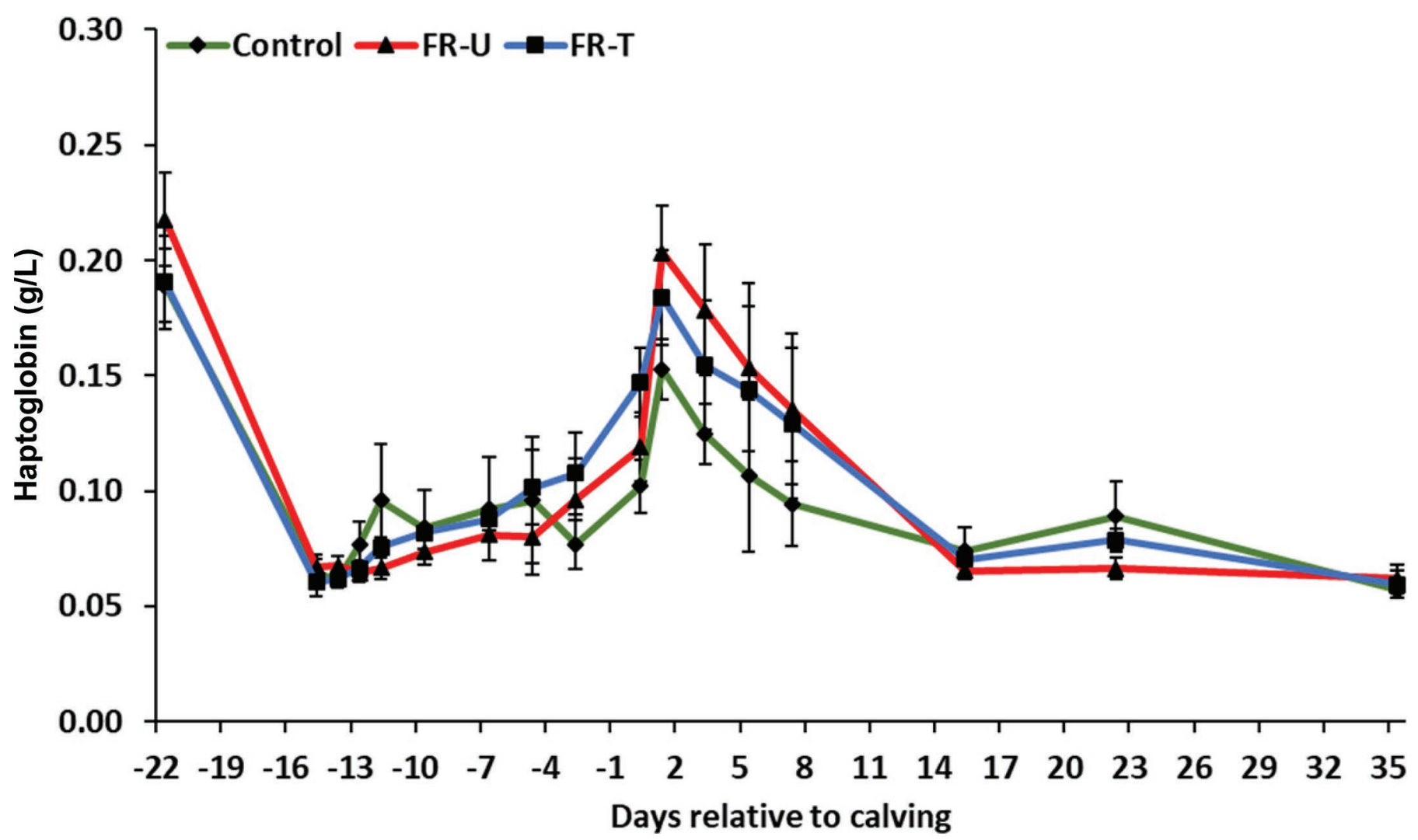

Figure 2. $\log _{10}$-scale LSM (accounting for parity and BCS) \pm SE of haptoglobin serum concentrations in 45 peripartum Holstein cows. Treatment groups consisted of control $(\mathrm{n}=13)$, feed restriction $(\mathrm{FR})$ untreated $(\mathrm{FR}-\mathrm{U} ; \mathrm{n}=15)$, and FR treated with meloxicam $(\mathrm{FR}-\mathrm{T}$; $\mathrm{n}=$ 17). Control cows were fed ad libitum, whereas FR-U and FR-T cows were reduced to $60 \%$ of their average intake for $4 \mathrm{~d}(-15$ to $-12 \mathrm{~d}$ from expected calving). The FR-T cows received meloxicam $(0.5 \mathrm{mg} / \mathrm{kg}$ of BW) once daily for $4 \mathrm{~d}$ ( -13 to $-10 \mathrm{~d}$ from expected calving). No differences were found between experimental groups at any time point $(P=0.8)$. 
peak NEFA concentration seen in early-postpartum cows. After calving, dairy cows typically have a 4- to 5 -fold increase in NEFA concentration (McCarthy et al., 2015) due to the homeorhetic drive to increase milk production coupled with inadequate DMI (Bauman and Currie, 1980). Therefore, this model was not sufficient to mimic the magnitude of early postpartum concentration of NEFA during the FR period.

Control cows had a greater concentration of BHB postpartum than did FR cows. Janovick et al. (2011) similarly found that controlled energy intake through FR in the late prepartum period was followed by lesser postpartum BHB concentrations. Postpartum, serum NEFA concentration, DMI, and milk yield did not differ among the treatments. Therefore, we speculate that the greater postpartum concentrations of BHB in the cows fed ad libitum may relate to setting hepatic metabolism by prepartum energy availability in excess of the maintenance requirement in the non-FR cows.

Fat mobilization produces proinflammatory cytokines (TNF- $\alpha$ and IL-6; Tilg and Moschen, 2008). In humans and in rodent models, in the context of obesity, macrophages in adipose contribute to chronic inflammation (Hotamisligil, 2006). Obese people (Osborn and Olefsky, 2012) and dairy cows in early lactation have elevated circulating NEFA, insulin resistance, and SI in common. There is evidence that in dairy cows during postpartum lipolysis, there is inflammation in adipose tissue (at least in diseased cows; Contreras et al., 2015, 2017). We hypothesized that cows undergoing substantial lipolysis (induced by FR) would similarly be in a state of SI. Release of positive APP (e.g., Hp) is triggered by proinflammatory cytokines that may originate from lipolysis (Loor et al., 2013). In studies by Bertoni et al. (2008) and Trevisi et al. (2012), cows were retrospectively divided into quartiles based on the liver functionality index, which they proposed. According to the authors, a low liver functionality index is indicative of impaired liver function and associated with SI (and reduced feed intake) and is characterized by increased plasma concentrations of $\mathrm{Hp}$ and bilirubin and reduced synthesis of albumin and cholesterol. In the present

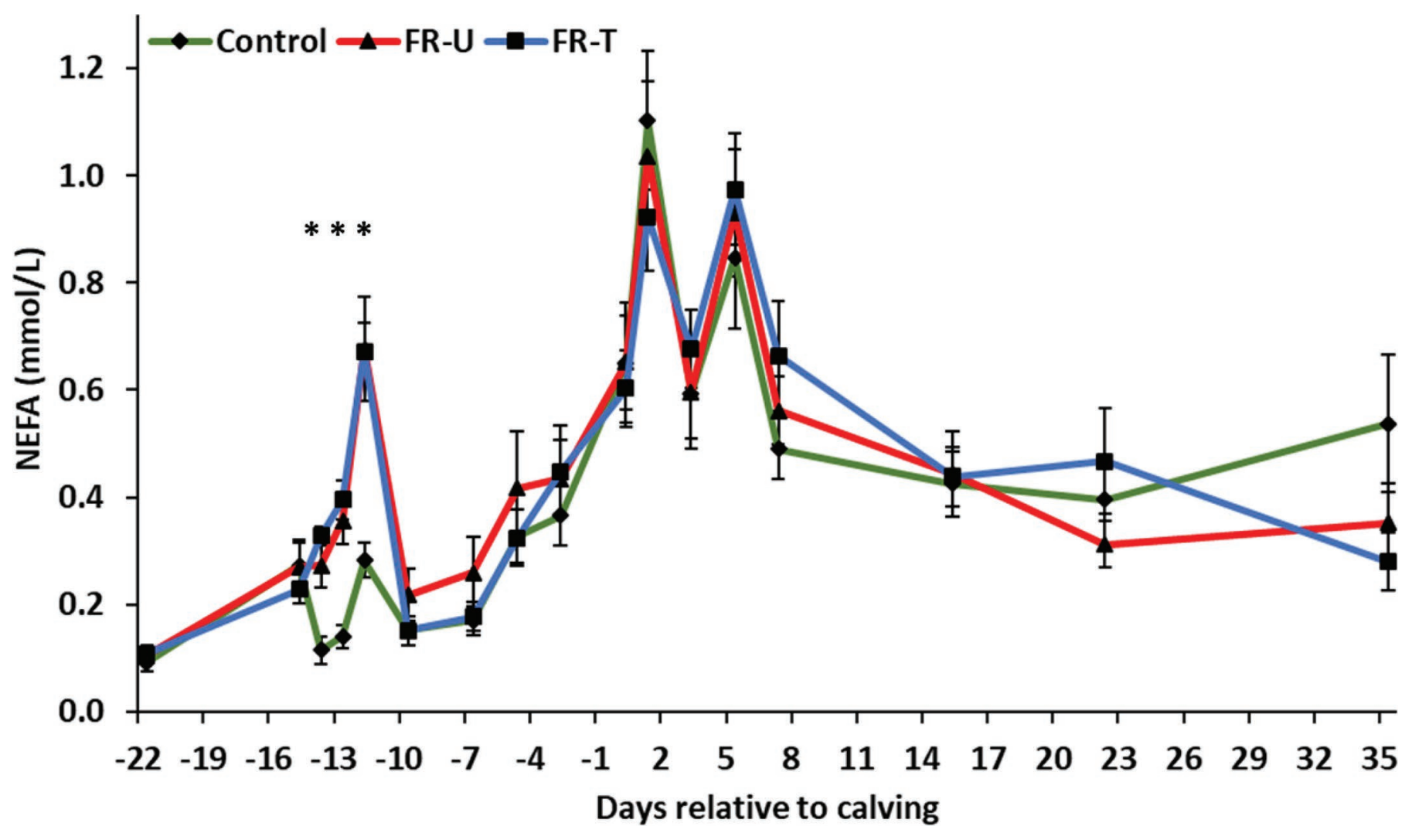

Figure 3. Least squares means (accounting for parity and BCS) \pm SE of serum nonesterified fatty acids (NEFA) concentrations in 45 peripartum Holstein cows. Treatment groups consisted of control $(\mathrm{n}=13)$, feed restriction $(\mathrm{FR})$ untreated $(\mathrm{FR}-\mathrm{U} ; \mathrm{n}=15)$, and FR treated with meloxicam (FR-T; $\mathrm{n}=17$ ). Control cows were fed ad libitum, whereas FR-U and FR-T cows were reduced to $60 \%$ of their average intake for $4 \mathrm{~d}$ ( -15 to $-12 \mathrm{~d}$ from expected calving). The FR-T cows received meloxicam $(0.5 \mathrm{mg} / \mathrm{kg}$ of BW) once daily for $4 \mathrm{~d}(-13$ to $-10 \mathrm{~d}$ from expected calving). Compared with the control group, NEFA concentrations in both FR groups increased from the second until the last day of FR (FR$\mathrm{U}: P=0.04,0.03$, and 0.004 on $-14,-13$, and $-12 \mathrm{~d}$, respectively; FR-T: $P=0.03,0.02$, and 0.002 on $-14,-13$, and $-12 \mathrm{~d}$, respectively). Asterisks indicate significant differences $(P<0.05)$ between the control and the FR groups. No differences were found between FR groups $($ FR$\mathrm{U}$ vs. FR-T $)$ at any time point $(P=0.8)$. 
study, the lipomobilization produced by the FR did not reach the peak concentrations seen in early-postpartum cows (Trevisi et al., 2012). This degree of fat mobilization coupled with the absence of proinflammatory precursors from the postpartum uterine environment did not generate detected SI. This prospective experiment failed to identify mechanisms associated with the onset of SI in the prepartum period. We were unable to replicate the substantial increase in serum Hp observed concurrently with a large, early decrease in prepartum DMI reported by Bertoni et al. (2009). In a similar model with 4-d FR but in the early postpartum period (24 to 27 DIM), Pires et al. (2019) produced high plasma NEFA and BHB concentrations, but no differences in markers for SI (milk IL-8, IL-1 $\beta$, and TNF- $\alpha$ ) were found between FR and control cows. We infer that experimental reduction in DMI of a magnitude even greater than is typical in the week before calving does not, by itself, trigger SI. Consequently, the efficacy of MEL to mitigate SI could not be demonstrated. Our thinking was that an immediate and substantial FR would perhaps be a slightly exaggerated stimulus of SI, but if FR models are to be pursued to study SI, more gradual declines and longer duration of FR should be explored.

The unexpectedly high concentrations of $\mathrm{Hp}$ and LBP observed at $-22 \mathrm{~d}$ are likely attributable to injected vaccination against coliform mastitis received by all cows shortly before the start of this experiment (approximately $-26 \mathrm{~d}$ ). Lipopolysaccharide binding protein concentrations in serum remained unchanged during the FR. These results are in accordance with the work of Piantoni et al. (2018), where a 50\% FR model for 5 consecutive days produced an increase of serum NEFA (2-fold) but did not affect the serum concentrations of LBP. Lack of serum LBP increase during the FR suggests that short-term feed deprivation models of $<50 \%$ do not affect the intestinal or ruminal barrier function; that is, this model apparently did not produce SI through the "leaky gut" mechanism.

We aimed to measure the serum levels of IL-1 $\beta$, IL6 , and TNF- $\alpha$ as markers of inflammation. However,

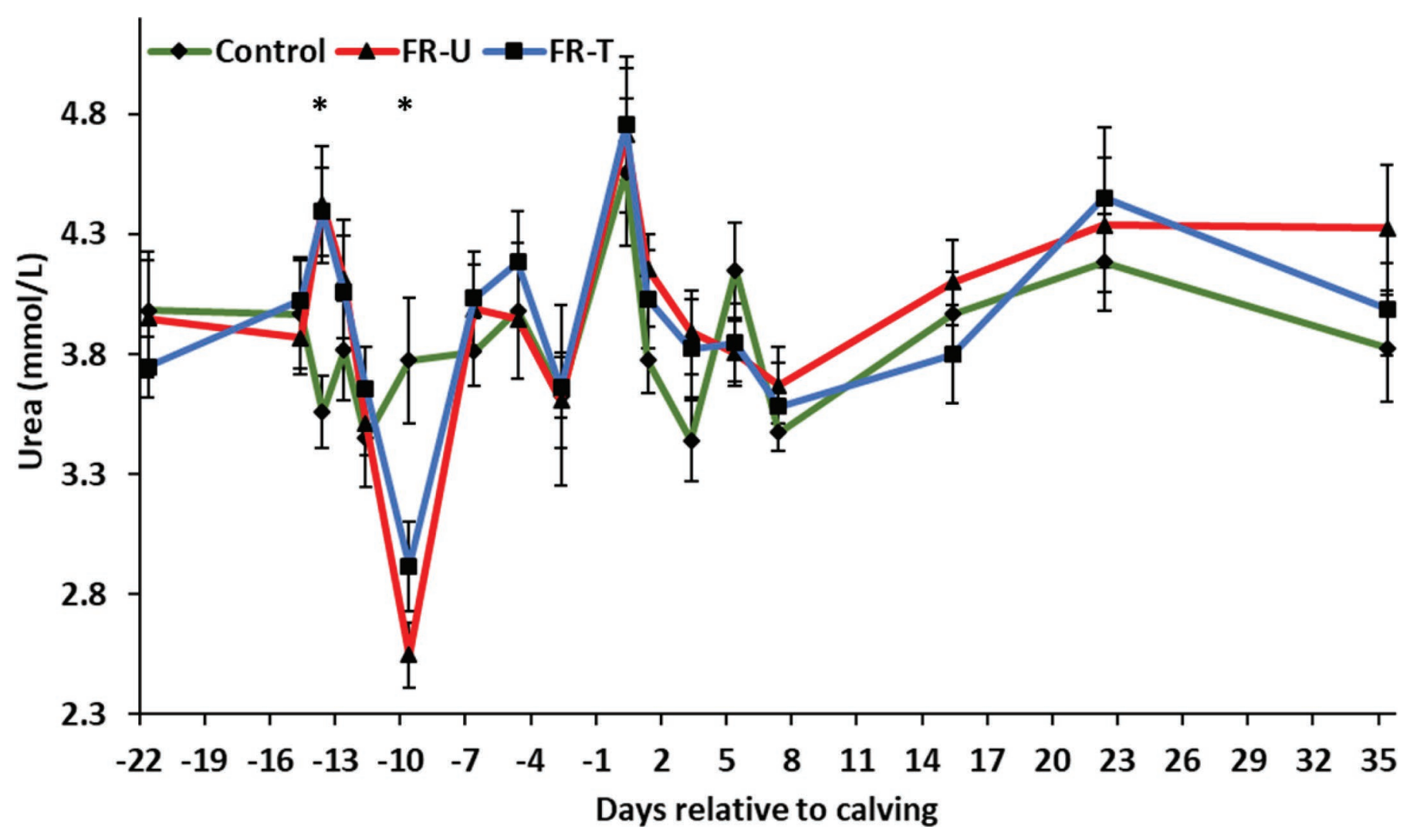

Figure 4. Least squares means (accounting for parity and BCS) \pm SE of serum urea concentrations in 45 peripartum Holstein cows. Treatment groups consisted of control $(\mathrm{n}=13)$, feed restriction $(\mathrm{FR})$ untreated $(\mathrm{FR}-\mathrm{U} ; \mathrm{n}=15)$, and FR treated with meloxicam $(\mathrm{FR}-\mathrm{T}$; $\mathrm{n}=$ 17). Control cows were fed ad libitum, whereas FR-U and FR-T cows were reduced to $60 \%$ of their average intake for $4 \mathrm{~d}(-15$ to $-12 \mathrm{~d}$ from expected calving). The FR-T cows received meloxicam $(0.5 \mathrm{mg} / \mathrm{kg}$ of BW) once daily for $4 \mathrm{~d}$ ( -13 to $-10 \mathrm{~d}$ from expected calving). Feed restriction increased serum urea concentrations compared with the control group on $-14 \mathrm{~d}$ (FR-U, $P=0.01 ; \mathrm{FR}-\mathrm{T}, P=0.04)$ but decreased serum urea concentrations on $-10 \mathrm{~d}$ from expected calving (FR-U, $P=0.001$; FR-T, $P=0.01)$. Asterisks indicate significant differences $(P<0.05)$ between the control and the FR groups. No differences were found between FR groups (FR-U vs. FR-T) at any time point $(P=0.8)$. 
the concentrations of these proinflammatory cytokines were not detectable (too low) in the serum of most cows, especially during the prepartum sampling period. Interestingly, one-third of the animals provided samples above the detection limit for IL- 6 and TNF- $\alpha$, suggesting that the overall concentration of cytokines is higher in specific cows. The ELISA methods we used for serum cytokines are the same as those described by Farney et al. (2011) for TNF- $\alpha$ and Trevisi et al. (2015) for IL-1 $\beta$ and IL-6. Although we hypothesized that the period of FR would lead to a state of SI, the low (undetectable) concentrations in many of the samples may reflect clinically healthy cows that, being prepartum, had no other inflammatory stimuli to compound whatever may have resulted from FR.

Disturbances in adipose tissue function (massive fat mobilization) can lead to insulin resistance and metabolic disorders (Montecucco and Mach, 2009; Contreras et al., 2010). In obese humans and those with type 2 diabetes, the metabolic profile includes elevated circulating concentrations of NEFA, TNF- $\alpha$, IL- 6 , and other cytokines that are indicative of elevated lipolysis, accompanied by insulin resistance (Slattery et al., 2004; Fontana et al., 2007). O'Boyle et al. (2006) showed similar results in overconditioned dairy cows in mid lactation. We saw no differences in serum insulin concentrations and glucose metabolism (insulin sensitivity) among experimental groups. However, it remains unclear whether this was a result of the failure to induce measurable SI or whether lactating dairy cows differ from people with respect to the linkages among obesity, chronic inflammation, and insulin resistance (Hotamisligil, 2006).

Increased serum urea concentrations occurred on the second day of FR $(-14 \mathrm{~d}$ from expected parturition) in both FR groups. However, urea returned to basal levels (similar to control) on the fourth day of restriction ( $-12 \mathrm{~d}$ from expected parturition) and was significantly lower than the control group just after the end of the FR period ( $-10 \mathrm{~d}$ from expected calving) when the FR cows had significantly higher DMI. The change in serum urea concentration lasted for $24 \mathrm{~h}$,

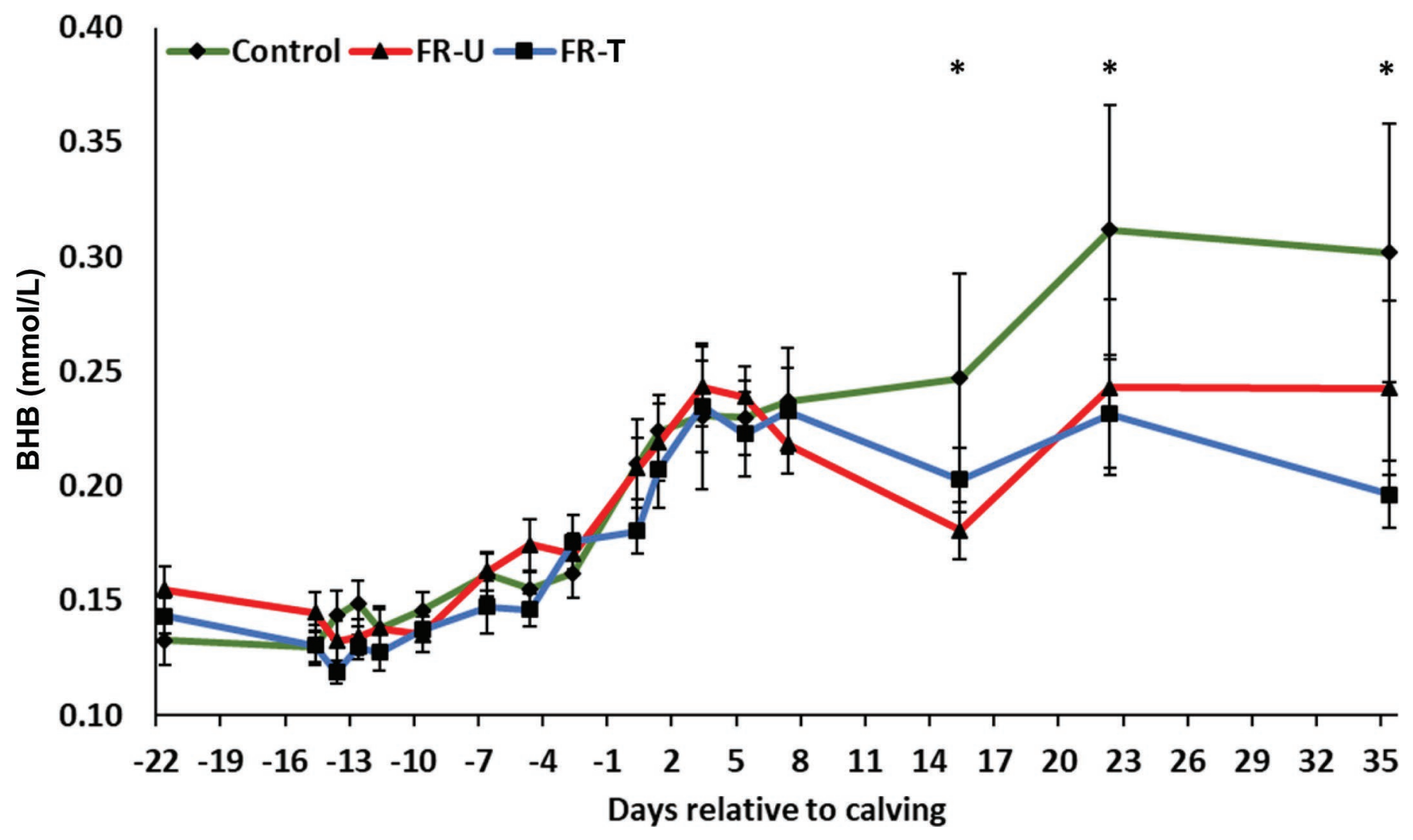

Figure 5. $\log _{10}$-scale LSM (accounting for parity and BCS) \pm SE of serum BHB concentrations in 45 peripartum Holstein cows. Treatment groups consisted of control $(\mathrm{n}=13)$, feed restriction $(\mathrm{FR})$ untreated $(\mathrm{FR}-\mathrm{U} ; \mathrm{n}=15)$, and $\mathrm{FR}$ treated with meloxicam $(\mathrm{FR}-\mathrm{T} ; \mathrm{n}=17)$. Control cows were fed ad libitum, whereas FR-U and FR-T cows were reduced to $60 \%$ of their average intake for $4 \mathrm{~d}(-15$ to $-12 \mathrm{~d}$ from expected calving). The FR-T cows received meloxicam $(0.5 \mathrm{mg} / \mathrm{kg}$ of BW) once daily for $4 \mathrm{~d}$ ( -13 to $-10 \mathrm{~d}$ from expected calving). Control cows had greater BHB concentrations compared with FR cows on 15,21 , and 35 d postpartum (FR-U: $P=0.08,0.07$, and 0.01 on 15,21 , and $35 \mathrm{~d}$, respectively: FR-T: $P=0.04,0.006$, and 0.0007 on 15,21 , and $35 \mathrm{~d}$, respectively). Asterisks indicate significant differences $(P<0.05)$ between the control and the FR groups. No differences were found between FR groups (FR-U vs. FR-T) at any time point $(P=0.8)$. 
suggesting a rapid ruminal adaptation to the altered amount of feed intake. In nonruminants, an increase in the concentration of urea in response to high-protein diets and during starvation periods has been described (Morris, 1992). The latter may explain the negative association between feed intake and serum urea in the current study. However, our results are contrary to those described in mid-lactation cows by Velez and Donkin (2005), where FR cows had a lower plasma and milk urea concentration from the first until the last day of FR compared with control cows. They suggested that the reduction in urea concentration was attributable to a lower ammonia load in the rumen due to reduced nitrogen intake in FR cows, as described by Jonker et al. (1998). We did not analyze the chemical characteristics of the ruminal fluid.

\section{CONCLUSIONS}

This model of FR for 4 consecutive days ( -15 to $-12 \mathrm{~d}$ from expected calving), designed to mimic the degree of reduced feed intake naturally seen in the week before calving, produced substantial fat mobilization based on the high concentrations of NEFA. However, this FR model did not generate SI (based on Hp, LBP, and albumin concentrations); thus, the ability of MEL to mitigate SI could not be properly assessed. Although our results indicate that SI was not a result of FR, our model did not replicate the pattern and duration of naturally occurring decreases in DMI around calving, in at least some cows. Therefore, reduced feed intake cannot be ruled out as a contributor to the initiation of SI in the peripartum period, and the mechanisms of onset of SI in the transition period of dairy cows remain unclear.

\section{ACKNOWLEDGMENTS}

Financial support for this study was provided by the Ontario Ministry of Agriculture, Food and Rural Affairs (Guelph, ON, Canada) and by Boehringer-Ingelheim Vetmedica (Burlington, ON, Canada). Special thanks to Laura Wright (University of Guelph, Guelph, ON, Canada) and the staff at the University of Guelph Livestock Research and Innovation Centre Dairy Facility (Elora, ON, Canada).

\section{REFERENCES}

Allen, M. S., and P. Piantoni. 2013. Metabolic control of feed intake: Implications for metabolic disease of fresh cows. Vet. Clin. North Am. Food Anim. Pract. 29:279-297.

Bates, D., M. Maechler, B. Bolker, and S. Walker. 2015. lme4: Linear mixed-effects models using Eigen and S4. R package version 1. Accessed Jun. 15, 2018. http://CRAN.R-project.org/package=lme4.
Bauman, D. E., and W. B. Currie. 1980. Partitioning of nutrients during pregnancy and lactation: A review of mechanisms involving homeostasis and homeorhesis. J. Dairy Sci. 63:1514-1529.

Bertoni, G., A. Minuti, and E. Trevisi. 2015. Immune system, inflammation and nutrition in dairy cattle. Anim. Prod. Sci. 55:943-948.

Bertoni, G., E. Trevisi, X. Han, and M. Bionaz. 2008. Effects of inflammatory conditions on liver activity in puerperium period and consequences for performance in dairy cows. J. Dairy Sci. 91:33003310 .

Bertoni, G., E. Trevisi, and R. Lombardelli. 2009. Some new aspects of nutrition, health conditions and fertility of intensively reared dairy cows. Ital. J. Anim. Sci. 8:491-518.

Bionaz, M., E. Trevisi, L. Calamari, F. Librandi, A. Ferrari, and G. Bertoni. 2007. Plasma paraoxonase, health, inflammatory conditions, and liver function in transition dairy cows. J. Dairy Sci. 90:1740-1750.

Bradford, B. J., K. Yuan, J. K. Farney, L. K. Mamedova, and A. J. Carpenter. 2015. Invited review: Inflammation during the transition to lactation: New adventures with an old flame. J. Dairy Sci. 98:6631-6650.

Brideau, C., C. Van Staden, and C. Chung Chan. 2001. In vitro effects of cyclooxygenase inhibitors in whole blood of horses, dogs, and cats. Am. J. Vet. Res. 62:1755-1760.

Cardoso, F. C., W. Sears, S. J. LeBlanc, and J. K. Drackley. 2011. Technical note: Comparison of 3 methods for analyzing areas under the curve for glucose and nonesterified fatty acids concentrations following epinephrine challenge in dairy cows. J. Dairy Sci 94:6111-6115.

Carpenter, A. J., C. M. Ylioja, C. F. Vargas, L. K. Mamedova, L. G. Mendonça, J. F. Coetzee, L. C. Hollis, R. Gehring, and B. J. Bradford. 2016. Hot topic: Early postpartum treatment of commercial dairy cows with nonsteroidal antiinflammatory drugs increases whole-lactation milk yield. J. Dairy Sci. 99:672-679.

Contreras, G. A., E. Kabara, J. Brester, L. Neuder, and M. Kiupel. 2015. Macrophage infiltration in the omental and subcutaneous adipose tissues of dairy cows with displaced abomasum. J. Dairy Sci. 98:6176-6187.

Contreras, G. A., N. J. O'Boyle, T. H. Herdt, and L. M. Sordillo. 2010. Lipomobilization in periparturient dairy cows influences the composition of plasma nonesterified fatty acids and leukocyte phospholipid fatty acids. J. Dairy Sci. 93:2508-2516.

Contreras, G. A., C. Strieder-Barboza, and W. Raphael. 2017. Adipose tissue lipolysis and remodeling during the transition period of dairy cows. J. Anim. Sci. Biotechnol. 8:41-53.

De Koster, J., R. K. Nelli, C. Strieder-Barboza, J. de Souza, A. L. Lock, and G. A. Contreras. 2018. The contribution of hormone sensitive lipase to adipose tissue lipolysis and its regulation by insulin in periparturient dairy cows. Sci. Rep. 8:13378.

DFC-NFACC (Dairy Farmers of Canada and the National Farm Animal Care Council). 2009. DFC-NFACC Code of Practices for the Care and Handling of Dairy Cattle. Dairy Farmers of Canada, Ottawa, ON, Canada.

Drackley, J. K. 1999. ADSA Foundation Scholar Award. Biology of dairy cows during the transition period: The final frontier? J. Dairy Sci. 82:2259-2273.

Dubuc, J., T. F. Duffield, K. E. Leslie, J. S. Walton, and S. J. LeBlanc. 2010. Risk factors for postpartum uterine diseases in dairy cows. J. Dairy Sci. 93:5764-5771.

EMEA (European Agency for the Evaluation of Medicinal Products) 2007. Scientific discussion, Metacam. CVMP/323/97. EMEA London, UK.

Farney, J. K., L. Mamedova, J. Coetzee, B. KuKanich, L. M. Sordillo, S. K. Stoakes, J. E. Minton, L. C. Hollis, and B. J. Bradford 2013a. Anti-inflammatory salicylate treatment alters the metabolic adaptations to lactation in dairy cattle. Am. J. Physiol. Regul. Integr. Comp. Physiol. 305:R110-R117.

Farney, J. K., L. Mamedova, J. Coetzee, J. Minton, L. Hollis, and B. Bradford. 2013b. Sodium salicylate treatment in early lactation increases whole-lactation milk and milk fat yield in mature dairy cows. J. Dairy Sci. 96:7709-7718. 
Farney, J. K., L. K. Mamedova, B. H. Godsey, and B. J. Bradford. 2011. Technical note: Validation of an ELISA for measurement of tumor necrosis factor alpha in bovine plasma. J. Dairy Sci. 94:3504-3509.

Ferguson, J. D., D. T. Galligan, and N. Thomsen. 1994. Principal descriptors of body condition score in Holstein cows. J. Dairy Sci. 77:2695-2703.

Fontana, L., J. C. Eagon, M. E. Trujillo, P. E. Scherer, and D. Klein. 2007. Visceral fat adipokine secretion is associated with systemic inflammation in obese humans. Diabetes 56:1010-1013.

Gabay, C., and I. Kushner. 1999. Acute-phase proteins and other systemic responses to inflammation. N. Engl. J. Med. 340:448-454.

Gallay, P., D. Heumann, D. Le, C. Barras, and M. P. Glauser. 1994. Mode of action of anti-lipopolysaccharide-binding protein antibodies for prevention of endotoxemic shock in mice. Proc. Natl. Acad. Sci. USA 91:7922-7926.

Grummer, R. R. 1995. Impact of changes in organic nutrient metabolism on feeding the transition cow. J. Anim. Sci. 73:2820-2833.

Hotamisligil, G. S. 2006. Inflammation and metabolic disorders. Nature 444:860-867.

Hothorn, T., F. Bretz, and P. Westfall. 2013. Package "multcomp". Accessed Jun. 15, 2018. http://cran.stat.sfu.ca/web/packages/ multcomp/multcomp.pdf.

Ingvartsen, K. L., and K. M. Moyes. 2015. Factors contributing to immunosuppression in the dairy cow during the periparturient period. Jpn. J. Vet. Res. 63:S15-S24.

Janovick, N. A., Y. R. Boisclair, and J. K. Drackley. 2011. Prepartum dietary energy intake affects metabolism and health during the periparturient period in primiparous and multiparous Holstein cows. J. Dairy Sci. 94:1385-1400.

Jonker, J. S., R. A. Kohn, and R. A. Erdman. 1998. Using milk urea nitrogen to predict nitrogen excretion and utilization efficiency in lactating dairy cows. J. Dairy Sci. 81:2681-2692.

Kindt, T. J., R. A. Goldsby, B. A. Osborne, and J. Kuby. 2007. Kuby Immunology. 6th ed. W. H. Freeman, New York, NY.

LeBlanc, S. 2010. Monitoring metabolic health of dairy cattle in the transition period. J. Reprod. Dev. 56:S29-S35.

LeBlanc, S. J. 2012. Interactions of metabolism, inflammation, and reproductive tract health in the postpartum period in dairy cattle. Reprod. Domest. Anim. 47:18-30.

Loor, J. J., G. Bertoni, A. Hosseini, J. R. Roche, and E. Trevisi. 2013. Functional welfare using biochemical and molecular technologies to understand better the welfare state of peripartal dairy cattle. Anim. Prod. Sci. 53:931-953.

Makimura, S., and N. Suzuki. 1982. Quantitative determination of bovine serum haptoglobin and its elevation in some inflammatory diseases. Nihon Juigaku Zasshi 44:15-21.

Marques, R. S., R. F. Cooke, C. L. Francisco, and D. W. Bohnert. 2012. Effects of twenty-four hours transport or twenty-four hours feed and water deprivation on physiologic and performance responses of feeder cattle. J. Anim. Sci. 90:5040-5046.

Matteo, G., C. Mauro, and M. Massimo. 2009. Cows response to glucose tolerance test (GTT) and periparturient diseases: Preliminary study. J. Dairy Sci. 92(E-Suppl. 1):385. (Abstr.)

McArt, J. A. A., D. V. Nydam, G. R. Oetzel, T. R. Overton, and P. A. Ospina. 2013. Elevated non-esterified fatty acids and $\beta$-hydroxybutyrate and their association with transition dairy cow performance. Vet. J. 198:560-570.

McCarthy, M. M., S. Manns, D. V. Nydam, T. R. Overton, and J. A. McArt. 2015. Short communication: Concentrations of nonesterified fatty acids and $\beta$-hydroxybutyrate in dairy cows are not well correlated during the transition period. J. Dairy Sci. 98:6284-6290.

Medzhitov, R. 2008. Origin and physiological roles of inflammation. Nature 454:428-435.

Miltenburg, C. L., T. F. Duffield, D. Bienzle, E. Scholtz, and S. J. LeBlanc. 2018. The effect of prepartum feeding and lying space on metabolic health and immune function. J. Dairy Sci. 101:52945306.

Montecucco, F., and F. Mach. 2009. Common inflammatory mediators orchestrate pathophysiological processes in rheumatoid arthritis and atherosclerosis. Rheumatology 48:11-22.
Montgomery, S. R., L. K. Mamedova, M. Zachut, G. Kra, S. Häussler, M. Vaughn, J. Gonzalez, and B. J. Bradford. 2019. Effects of sodium salicylate on glucose kinetics and insulin signaling in postpartum dairy cows. J. Dairy Sci. 102:1617-1629.

Morino, K., K. F. Petersen, and G. I. Shulman. 2006. Molecular mechanisms of insulin resistance in humans and their potential links with mitochondrial dysfunction. Diabetes 55:S9-S15.

Morris, S. M. Jr. 1992. Regulation of enzymes of urea and argininesynthesis. Annu. Rev. Nutr. 12:81-101.

Mulligan, F. J., and M. L. Doherty. 2008. Production diseases of the transition cow. Vet. J. 176:3-9.

O'Boyle, N., C. M. Corl, J. C. Gandy, and L. M. Sordillo. 2006. Relationship of body condition score and oxidant stress to tumor necrosis factor expression in dairy cattle. Vet. Immunol. Immunopathol. 113:297-304

Osborn, O., and J. M. Olefsky. 2012. The cellular and signalling networks linking the immune system and metabolism in disease. Nat. Med. 18:363-374.

Piantoni, P., M. A. Abeyta, G. F. Schroeder, H. A. Ramírez-Ramírez, H. A. Tucker, and L. H. Baumgard. 2018. Induction of leaky gut through feed restriction or abomasal infusion of resistant starch in healthy post-peak lactating cows. J. Dairy Sci. 101(E-Suppl. 2):228. (Abstr.)

Pires, J. A. A., K. Pawlowski, J. Rouel, C. Delavaud, G. Foucras, P. Rainard, P. Germon, and C. Leroux. 2019. Undernutrition modifies metabolic responses to intramammary lipopolysaccharide but has limited effects on inflammation indicators in early lactation cows. J. Dairy Sci. 102:5347-5360.

Schwartzkopf-Genswein, K. S, K. A. Beauchemin, D. J. Gibb, D. H Crews Jr., D. D. Hickman, M. Streeter, and T. A. McAllister. 2003. Effect of bunk management on feeding behavior, ruminal acidosis and performance of feedlot cattle: A review. J. Anim. Sci. 81:E149-E158.

Skinner, J. G., R. A. L. Brown, and L. Roberts. 1991. Bovine haptoglobin response in clinically defined field conditions. Vet. Rec. 128:147-149

Slattery, M. L., W. Samowitz, M. Hoffman, K. N. Ma, T. R. Levin, and S. Neuhausen. 2004. Aspirin, NSAIDs, and colorectal cancer: Possible involvement in an insulin-related pathway. Cancer Epidemiol. Biomarkers Prev. 13:538-545.

Suojala, L., T. Orro, H. Jarvinen, J. Saatsi, and S. Pyorala. 2008. Acute phase response in two consecutive experimentally induced E. coli intramammary infections in dairy cows. Acta Vet. Scand. $50: 18-27$

Sweet, M. J., and D. A. Hume. 1996. Endotoxin signal transduction in macrophages. J. Leukoc. Biol. 60:8-26.

Tavakkol, A., F. A. Simmen, and R. C. M. Simmen. 1988. Porcine insulin-like growth factor-I (pIGF-I): Complementary deoxyribonucleic acid cloning and uterine expression of messenger ribonucleic acid encoding evolutionarily conserved IGF-I peptides. Mol. Endocrinol. 2:674-681.

Tilg, H., and A. R. Moschen. 2008. Insulin resistance, inflammation, and non-alcoholic fatty liver disease. Trends Endocrinol. Metab. 19:371-379.

Trevisi, E., M. Amadori, S. Cogrossi, E. Razzuoli, and G. Bertoni. 2012. Metabolic stress and inflammatory response in high-yielding, periparturient dairy cows. Res. Vet. Sci. 93:695-704.

Trevisi, E., N. Jahan, A. Ferrari, and A. Minuti. 2015. Pro-inflammatory cytokine profile in dairy cows: Consequences for new lactation. Ital. J. Anim. Sci. 14:285-292.

Velez, J. C., and S. S. Donkin. 2005. Feed restriction induces pyruvate carboxylase but not phosphoenolpyruvate in dairy cows. J. Dairy Sci. 88:2938-2948.

Wittrock, J. A. M. 2012. Associations among neutrophil function, metabolic indicators, and reproductive health in dairy cows. MSc Thesis. University of Guelph, Guelph, ON, Canada.

Zachut, M., H. Honig, S. Striem, Y. Zick, S. Boura-Halfon, and U. Moallem. 2013. Periparturient dairy cows do not exhibit hepatic insulin resistance, yet adipose-specific insulin resistance occurs in cows prone to high weight loss. J. Dairy Sci. 96:5656-5669. 